\title{
INCENTIVES LEADING TO EDUCATION OF MANAGERS IN THE FIELD OF INFORMATION- COMMUNICATION TECHNOLOGIES
}

Vladimír BOLEK*, Ekonomická univerzita v Bratislave, Slovenská republika

Přijato: 14. 7. 2016 / Akceptováno: 6. 9.2016

Typ článku: Výzkumná štúdia

DOI: $10.5507 /$ jtie.2016.029

Abstract: Managers, who want to prosper, must not only support ICT development, but also learn to actively use the ICT. Continuing education is a significant means of developing managers' abilities. The managers acquire knowledge and skills not only by graduate and postgraduate education, but by various forms of lifelong learning as well. Managers of ICT education led a number of incentives. The most important are interested in personal growth, the possibility of a better application, a career. For these initiatives have a significant impact several factors: gender, age, education, job position.

Key words: information and communication technologies, education, lifelong learning, information literacy, manager

\section{PODNETY VEDÚCE K VZDELÁVANIU MANAŽÉROV V OBLASTI INFORMAČNO-KOMUNIKAČNÝCH TECHNOLÓGIÍ}

Abstrakt: Manažéri organizácii, ktorí chcú prosperovat, musia nielen podporovat' budovanie IKT, ale sami ich ovládat' a aktívne využivat'. Dôležitým prostriedkom formovania schopností manažérov je sústavné vzdelávanie. Vedomosti a zručnosti ziskajú nielen graduálnym a postgraduálnym štúdiom, ale $i$ rôznymi formami celoživotného vzdelávania. Manažérov ku vzdelávaniu v oblasti IKT vedie viacero stimulov, podnetov. Medzi najvýznamnejšie patrí záujem o osobný rast, možnost' lepšieho uplatnenia, budovanie kariéry. Na tieto podnety majú signifikantný vplyv viaceré faktory: pohlavie, vek, vzdelanie, pracovná pozícia.

Klúčové slová: informačno-komunikačné technológie, vzdelávanie, celoživotné vzdelávanie, informačná gramotnost', manažér

*Autor pre korešpondenciu: vladimir.bolek@euba.sk 


\section{1 Úvod}

Výkon riadiacich funkcií manažéra sa $\mathrm{v}$ súčasnej dobe uskutočňuje na základe informácií, rôznych informačných tokov s využívaním informačno-komunikačných technológií (IKT) vo všetkých sférach spoločnosti. Kubiatko (2013) konštatuje, že v súčasnosti je typické využívanie IKT vo všetkých aspektoch l'udského života. Z nášho pohl'adu je ich znalost', zručnost' a správna aplikácia d’alšou zo súboru požiadaviek organizácií. Technologický pokrok v oblasti IKT rastie enormným tempom. Získavanie, rozvíjanie znalostí a zručností je nevyhnutnost'ou manažérov. Nové poznatky je možné získat' všetkými formami vzdelávania, avšak predovšetkým celoživotným vzdelávaním.

Hlavným ciel'om príspevku je identifikovat' vplyv na podnety vedúce k vzdelávaniu manažérov v oblasti IKT. Hlavný ciel' napĺnajú viaceré parciálne ciele: identifikovat' aktuálny stav v celoživotnom vzdelávaní manažérov v oblasti IKT na základe poznatkov $\mathrm{z}$ domácej, zahraničnej literatúry a uskutočneného prieskumu určit’ podnety vedúce $\mathrm{k}$ ich vzdelávaniu a identifikovat' signifikantné faktory na hladine významnosti $\alpha=0,05$, ktoré ich ovplyvňujú. Príspevok je čiastkovým výstupom z komplexného výskumu zameraného na informačnú gramotnost' manažérov, ktorý doposial' v podmienkach Slovenskej republiky absentoval, v čom spočíva aj jedinečnost' výskumu. V oblasti celoživotného vzdelávania dospelých je viacero prieskumov, avšak bez zamerania na túto špecifickú skupinu. Realizované prieskumy sú zamerané skôr všeobecne na ciel'ovú skupinu dospelých alebo nezamestnaných. Významným projektom je Create-MotivateLearn a výskumná štúdia Inovatívne spôsoby motivácie dospelých k vzdelávaniu (Balaisiene, 2011). Výsledkom bolo na základe identifikovaných faktorov vytvorit' sériu tvorivých stratégií podporujúcich kritické myslenie, ktoré môžu byt' využité pedagógmi $\mathrm{v}$ oblasti vzdelávania dospelých pre úspešnejšie motivovanie dospelých $\mathrm{k}$ účasti na celoživotnom vzdelávaní.

Významný americký autor v oblasti vzdelávania manažérov Richard Farson (1997) v knihe Management Of the Absurde Paradoxes in Leadership pojednáva o manažéroch takto: „Sú manažéri dobrí, dokonca aj výborní, ale nie špecializovaní na riadenie. Opýtajte sa špičkových manažérov, v čom spočíva ich schopnost' výborne viest' l'udí a banalita ich odpovede vás utvrdí v pocite, že tí l'udia nevedia skoro nič o tom, čo ich robí výnimočnými. Ak teda schopnost' viest' l'udí nie je vecou špecializácie, alebo ak riadenie medzil'udských vzt’ahov nie je výhradne len vecou používanej techniky, potom táto oblast' nemôže byt' rozvíjaná len tréningom. Ako teda týchto l'udí zdokonal'ovat'? Správna odpoved’ znie: vzdelávaním“. S myšlienkou uvedeného autora sa možno stotožnit' i v súčasnosti, lebo kvalita riadenia organizácie a rozhodnutia manažérov sú ovplyvňované nielen skúsenost’ami z praxe, ale najmä sústavným, celoživotným vzdelávaním.

Manažéri si uvedomujú, že vedomosti nadobudnuté formálnym vzdelávaním už nepostačujú, že si ich musia dopĺn̆at', prehlbovat' a rozširovat' v súlade s požiadavkami podnikov v turbulentne sa rozvíjajúcej spoločnosti. A tak sa dostáva do popredia otázka d’alšieho vzdelávania ako súčasti celoživotného vzdelávania, a to nielen u nás, ale i vo všetkých krajinách Európskej únie, ba i v celosvetovom meradle. Celosvetový rozmer potvrdzuje vo svojej štúdii aj Kokles (2015). Nové vzniklé situácie, objavujúce sa nečakane, prinášajú potrebu učenia, vzdelávania. Medzi týmito pojmami je zásadný rozdiel, pretože učenie implicitne predstavuje myšlienku osobnej zodpovednosti 
za rozvoj vlastného vzdelávania. $\mathrm{Z}$ pedagogického hl'adiska pojem celoživotné vzdelávanie (lifelong education) predstavuje skôr „strategický princíp koordinácie a kooperácie zložiek národných subsystémov vzdelávania“ (Švec, 2002). Pojem celoživotné učenie (lifelong learning) sa týka individuálnej aktivity človeka a slúži „na označenie dimenzie dlhodobosti, celoživotnosti javu a procesu l'udského učenia sa v rozmanitých formálnych učebných situáciách“ (Švec, 2002). Z uvedeného vyplýva, že učenie sa viac vztahuje na celostný mnohostranný rozvoj osobnosti manažéra, kým celoživotné vzdelávanie na stratégiu určenú na riešenie implikácií spoločenských a ekonomických zmien. $V$ podstate $\mathrm{v}$ živote manažéra tieto dva pojmy na seba nadväzujú a formujú jeho osobnost'.

Vedenie moderných podnikov, organizácií si uvedomuje, že sústavné vzdelávanie manažérov v každej oblasti spoločenského života je nevyhnutné. Manažéri musia disponovat' takými kompetentnost’ami (znalost’ami, zručnost'ami, vedomostami), aby ich dokázali uplatnit' nielen pri riadení operatívnom, taktickom, ale predovšetkým pri strategickom rozhodovaní o dôležitých veciach, aby dokázali rozpoznávat' nové hrozby, príležitosti, riziká v konkurenčnom prostredí.

Všeobecným fenoménom súčasnej doby je zmena, ktorú vyvolávajú viaceré faktory, v prvom rade mimoriadny pokrok v IKT zasahujúci do všetkých sfér života spoločnosti, nevynímajúc ani sféru vzdelávania. IKT nie sú len nástrojom riadenia a rozhodovania organizácie, ale sú i prostriedkom vzdelávania. V procese vzdelávania a rozvoji manažérov sa využíva široká škála metód učenia na báze počítačov CBL - computer based learning, pretože ako tvrdí Prokopenko a Kubr (1996) „počítače sú technológiou, ktorá je schopná uskutočňovat' samostatné vzdelávacie kurzy.“ Teda znalost' IKT nie je len nutnou požiadavkou kladenou na manažérov, ale sú aj užitočným nástrojom d’alšieho vzdelávania, a preto je žiaduce zohl'adnit' vzájomnú prepojenost' IKT ako predmetu a nástroja vzdelávania.

Celoživotné vzdelávanie sa neustále prehodnocuje so zameraním na vy̌šiu kvalitu formálneho i neformálneho vzdelávania, na flexibilitu v možnostiach vzdelávania, zodpovedný prístup k vzdelávaniu, rozvoj schopností atd’. Všetky medzinárodné aktivity, výzvy, programy vychádzajú z podstaty, že modernú spoločnost' treba chápat' ako učiacu sa, založenú na vedomostiach $\mathrm{s}$ využívaním nových technológií a IKT. V celoživotnom vzdelávaní sa mnohé štáty snažia zvýšit kvantitu a kvalitu vzdelávania dospelých a zabezpečit' kompatibilitu a vzájomné doplnenie medzi aktivitami. „Prijatie prístupu celoživotného vzdelávania má dôležité implikácie pre štruktúry, úlohy a zodpovednosti tých, ktorých sa to týka, právomoci jedincov, zabezpečenie vzdelávacích možností, celkovú kvalitu zabezpečenia a uznanie vzdelania“" (Keogh, 2007).

\section{Koncepčný a legislatívny rámec celoživotného vzdelávania}

V súlade s celosvetovými procesmi bola na Slovensku v roku 2002 prijatá Koncepcia d’alšieho vzdelávania v Slovenskej republike, ktorá bola prvým krokom schválenia Koncepcie celoživotného vzdelávania v Slovenskej republike v roku 2004. Ďalšie vzdelávanie bolo upravené zákonom NR SR č. 386/1997 Zb. o d’alšom vzdelávaní s platnostou od 1. 1. 1998 ako súčast' vzdelávacej sústavy SR pre každého podl'a schopností a záujmov, ktorý bol nahradený a rozšírený zákonom NR SR č. 568/2009 Z. z. o celoživotnom vzdelávaní. Zákon definuje celoživotné vzdelávanie takto: „Celoživotné vzdelávanie sú všetky aktivity, ktoré sa uskutočňujú v priebehu života 
s ciel'om zlepšit' vedomosti, zručnosti a schopnosti. Celoživotné vzdelávanie ako základný princíp výchovy a vzdelávania uplatňovaný vo vzdelávacej sústave Slovenskej republiky tvorí:

- školské vzdelávanie,

- a d’alšie vzdelávanie nadväzujúce na stupeň vzdelania dosiahnutý v školskom vzdelávaní.“

Podla Európskej komisie (Eurostat, 2012) „celoživotné vzdelávanie zahŕňa všetky aktivity cielavedomého učenia, či už formálne, neformálne alebo informálne, vykonávané priebežne s ciel'om zlepšenia vedomostí, zručností a kompetencií. Úmysel alebo ciel' naučit', predstavuje kritický bod, ktorý odlišuje tieto aktivity od nonlearningových aktivít, akými sú kultúrne či športové aktivity.“

Tvrdíme, že celoživotné vzdelávanie sa stáva významným harmonizujúcim nástrojom súladu medzi požiadavkami zamestnávatel’ov a kompetentnostou zamestnancov, medzi ktorých sa zarad’ujú i manažéri. Vzdelávanie manažérov je teda integrálnou súčastou celoživotného vzdelávania, ktorá v praxi nadobúda konkrétnu podobu a samotná prax manažéra si jej realizáciu vynucuje. Vzdelávanie sa dostáva do popredia ako celoživotný proces, kde elementárnym faktorom rozvoja manažéra je jeho sebavzdelávanie ako proces tvorby vlastnej osobnosti, ktoré sa má uskutočňovat' sústavne, v práci, v každodennom živote a aj vo vol'nom čase. Existuje vel'ká variantnost' vzdelávacích príležitostí, ktoré zodpovedajú rôznym individuálnym potrebám manažérov i organizácií: prednášky, semináre, kurzy, tréningy...

Integrovaný akčný program v oblasti celoživotného vzdelávania na obdobie 2007 2013 s udržatel'ným rastom podla Šubertovej (2009) zahŕňal štyri osobitné programy: COMENIUS pre všeobecno-vzdelávacie činnosti týkajúce sa škôl až do konca vyššieho stredoškolského stupňa; ERASMUS zameraný na činnosti vzdelávania a odbornej prípravy na vyššom vzdelávacom stupni; LEONARDO DA VINCI pre všetky iné aspekty odborného vzdelávania a odbornej prípravy; a GRUNDTVIG pre vzdelávanie dospelých. Program LEONARDO DA VINCI je pre podniky najdôležitejší, lebo podporuje inovačné nadnárodné iniciatívy na podporu znalostí, talentu a zručností potrebných na úspešnú integráciu do pracovného života a úplné využitie občianstva.

Na základe poznania získaného štúdiom literárnych prameňov možno konštatovat', že existuje vel’a modelov, metód, systémov vzdelávania manažérov, neexistuje však systém špeciálne navrhnutý pre vzdelávanie manažérov v oblasti IKT.

„Európska únia zabezpečuje smer pre národné orientácie, v ktorých plne rešpektuje zodpovednost' a autonómiu členských štátov pri budovaní svojich vlastných výchovnovzdelávacích systémov. V tomto kontexte všetky štáty poskytujú dôkaz o dopade lisabonskej agendy na ich politické priority a túto agendu niekol'ko štátov konkrétne nazýva politickým kompasom (Bulharsko, Česká republika, Grécko, Španielsko, Lotyšsko, Malta a Pol'sko)“(Keogh, 2007).

\section{Metodika a metódy práce}

Výsledky práce, skúmania sú naplnené pomocou čiastkovej empirickej metódy pozorovania dotazníkovým prieskumom. Zámerom bolo zapojit' do tohto prieskumu manažérov v rámci Slovenskej republiky. Objektom skúmania je ciel’ová skupina manažérov rôznych úrovní a odvetví: štátneho sektora, verejného sektora, družstevného sektora, súkromného sektora, výrobnej sféry i nevýrobnej sféry, bez členenia organizácií 
podla organizačno-právnych foriem. Dotazník bol distribuovaný 200 manažérom využitím elektronickej komunikácie. Dotazník pozostával z 27 otázok. V dotazníku boli 4 otvorené otázky a 23 uzatvorených otázok.

Pri procese zostavovania dotazníka sme vychádzali z analýzy jednotlivých problémových okruhov a odôvodnenej konštruktovej, obsahovej i kritériovej validity. Obsahová konštrukcia dotazníka vychádzala z rozsiahlej analýzy problematiky. Reliabilita, teda presnost' a spol'ahlivost' dotazníka, bola determinovaná tromi faktormi: početnost'ou položiek, homogenitou a zložitost'ou úloh. V sprievodnom liste boli oslovení manažéri ubezpečení o dodržaní etických zásad: zachovanie dôvernosti informácií a anonymity. Dotazník bol distribuovaný 02/2015 manažérom všetkých úrovní manažmentu s pokrytím celej Slovenskej republiky. Návratnost' dotazníka (ukončený zber dát 10/2015) bola 180 respondentov, čo tvorí východiskový podklad pre čiastkové kvantitatívne analýzy. Respondenti v dotazníku odpovedali na uvedené otázky a zaznamenali aj mieru gramotnosti v jednotlivých analyzovaných nástrojoch, ktoré sa merali na bodovej stupnici 0 - 100. Odpovede respondentov boli merané pomocou poradových, intervalových a likertových škál.

Štruktúra analyzovanej vzorky 180-tich respondentov je nasledovná. Prieskumu sa zúčastnili manažéri podnikov a organizácií. $66,11 \%$ manažérov bolo z nevýrobných a $33,89 \%$ z výrobných podnikov a organizácií. Najviac zastúpené boli podniky s právnou formou obchodnej spoločnosti $80,00 \%$. Manažérov jednotlivých podnikov sme segmentovali do 3 skupín, podla pracovnej pozície: 1 - operatívni manažéri $32,22 \%, 2$ - taktickí manažéri - 42,78\%,3 - vrcholoví manažéri - 25,00 \%. Toto kritérium bolo často využívané pri jednotlivých štatistických analýzach. Manažéri mali najčastejšie dosiahnuté vysokoškolské vzdelanie II. stupňa - 69,44 \%. Ďalšie podrobné charakteristiky výskumnej vzorky uvádzame pri prezentovaní výsledkov analýz v časti výsledky práce.

Okrem základných štatistických metód popisnej štatistiky, korelácie, extrapolácie a korelačnej závislosti sme využili aj systémové metódy, pomocou ktorých sme hladali väzby medzi jednotlivými problematikami. Pri štatistickej analýze sme pracovali $\mathrm{s}$ aplikačným softvérom SPSS od spoločnosti IBM, ktorého upravené výstupy sú súčastou článku. Využité sú aj kvalitatívne metódy. Pod pojmom kvalitatívny prieskum chápeme predovšetkým postupy založené na „kvalitatívnej“, resp. „neštatistickej“ analýze, hoci táto môže byt' kombinovaná $\mathrm{s}$ kvantitatívnymi údajmi a postupmi, napríklad na overenie záverov vyplývajúcich z kvalitatívnej analýzy, či môže sama ilustrovat', alebo vyjasňovat' kvantifikované výsledky prieskumu. Vyhranené oddel'ovanie kvantitatívneho a kvalitatívneho prieskumu pokladáme za prekonané. Ich spoločným ciel'om je zabezpečit' najvyššiu kvalitu prieskumu. Dve podstatné zložky rozdielnosti medzi kvantitatívnym a kvalitatívnym prieskumom uvádza aj Kusá (2005).

Pri analýze vplyvu jednotlivých faktorov na podnety vedúce $\mathrm{k}$ vzdelávaniu manažérov v oblasti IKT sme pri testovaní normálneho rozdelenia dát využívali Leveneho test, následne po splnení, resp. nesplnení podmienky sme uplatňovali parametrické a neparametrické testy.

\section{Výsledky práce}

Výsledky práce vychádzajú z rozsiahleho, časovo náročného prieskumu, uskutočneného vo viacerých fázach, ktorý bol realizovaný na Slovensku. Z analýzy 
potreby vzdelávania manažérov pred a po nástupe do zamestnania konštatujeme, že pred nástupom do zamestnania pocit'ovalo potrebu vzdelávat' sa v oblasti IKT len 14,44 \% respondentov. Už po nástupe do zamestnania je citel’ný posun. Vzdelávalo sa 40,56 \% respondentov, $\mathrm{z}$ toho viac ako dve tretiny na pokyn organizácie. Manažéri medzeru v zručnostiach a znalostiach pocitujú viac po nástupe do zamestnania. Až 53,85\% respondentov sa vzdelávalo $\mathrm{v}$ oblasti IKT aj pred nástupom, a aj po nástupe do zamestnania, aby permanentne dokázali spĺňat' požiadavky zamestnávatel’a.

U manažérov, ktorí sa vzdelávajú, tvorí vzdelávanie sa v oblasti IKT $\bar{x}=39,99 \%$ podielu z celkového vzdelávania. Najčastejšie sa vyskytujúcou hodnotou percentuálneho podielu vo vzdelávaní v IKT je $\hat{\bar{x}}=40 \%$, čo je aj $\tilde{x}$.

Postoj manažérov $\mathrm{k}$ vzdelávaniu $\mathrm{v}$ oblasti IKT je pozitívny. Viac ako polovica respondentov má pozitívny vzt’ah ku vzdelávaniu v IKT, len 1,67 \% má ku vzdelávaniu negatívny vztah.

\begin{tabular}{|l|r|r|r|r|r|}
\hline \multirow{2}{*}{ Pracovná pozícia } & \multicolumn{2}{|c|}{ negatívny } & \multicolumn{1}{c|}{ neutrálny } & \multicolumn{2}{c|}{ pozitívny } \\
\cline { 2 - 7 } & \multicolumn{1}{|c}{$\mathbf{1}$} & \multicolumn{1}{c|}{$\mathbf{3}$} & \multicolumn{4}{c|}{$\mathbf{5}$} \\
\hline Operatívny manažment & 0 & 1 & 15 & 19 & 23 \\
\hline Taktický manažment & 1 & 2 & 11 & 17 & 46 \\
\hline Vrcholový manažment & 2 & 0 & 8 & 15 & 20 \\
\hline Celkový súčet & $\mathbf{1 , 6 7} \%$ & $\mathbf{1 , 6 7} \%$ & $\mathbf{1 8 , 8 9} \%$ & $\mathbf{2 8 , 3 3 \%}$ & $\mathbf{4 9 , 4 4} \%$ \\
\hline
\end{tabular}

\section{Tab. č. 1: Postoj manažérov $k$ vzdelávaniu v IKT}

$56,11 \%$ podnikov má v strategickom pláne organizácie zakomponované vzdelávanie $\mathrm{v}$ oblasti IKT. Absencia zakomponovaného vzdelávania v oblasti IKT v strategickom pláne je zväšša u nevýrobných podnikov, a to $49 \%$ : $34 \%$. Existencia strategického plánu s častou vzdelávania v oblasti IKT je u výrobných podnikov väčšia $65 \%: 51 \%$. Súčastou naplnenia strategického plánu býva aj podpora manažérov organizáciou vo vzdelávaní v oblasti IKT.

70,55 \% podnikov podporuje manažérov vo vzdelávaní v oblasti IKT aktívne, čo hodnotíme ako pozitívnu skutočnost' vo vztahu podnikov a manažérov v podpore vzdelávania. Avšak $15 \%$ podnikov, ktoré majú zakotvené v strategickom pláne vzdelávanie v oblasti IKT manažérov vo vzdelávaní nepodporuje.

Až $80,15 \%$ organizácií plne hradí výdavky súvisiace so vzdelávaním manažérov v oblasti IKT. 19,85 \% organizácií uhrádza len čast' výdavkov. Podniky zároveň poskytujú svojim zamestnancom aj iné špecifické formy podpory, a to až 56,99 \% tvorí vzdelávanie $\mathrm{v}$ rámci pracovného času mimo pracoviska, čo manažéri považujú za pozitívum. Manažéri najviac oceňujú vzdelávanie $\mathrm{v}$ rámci pracovného času priamo na pracovisku, čo podporuje $30,11 \%$ podnikov. Vzhl'adom na požiadavky, špecifiká vzdelávacích kurzov a školení, nie je vždy možné uskutočnit' vzdelávanie priamo na pracovisku. Manažéri oceňujú aj podporu formou motivujúceho ohodnotenia po úspešnom absolvovaní vzdelávania, ktorú podporuje len 3,23\% organizácií. 7,53\% organizácií umožňuje vzdelávanie priamo na pracovisku, avšak mimo pracovný čas zamestnanca. Sprístupnenie manuálov a príručiek na prácu v aplikáciách je dostupné, ak 
to dovolujú interné predpisy spoločnosti. Vzdelávanie mimo pracovného času a mimo pracoviska nie je ovplyvňované zamestnávatel'om.

Manažéri v otázke formy vzdelávania v oblasti IKT mohli zvolit' viacero možností foriem vzdelávania. Až 55,87 \% respondentov volí formálne a neformálne vzdelávanie, ktoré býva ukončené osvedčením. Informálne vzdelávanie, ktoré utvára spoločnost' a okolie manažéra tvorí $19,83 \%$ zhodne so samoštúdiom. E-learningovú formu vzdelávania využíva len $4,45 \%$ respondentov, čo je pravdepodobne spôsobené špecifikom vzdelávania IKT.

V tejto časti sme sa následne dopytovali respondentov, či sa plánujú v priebehu jedného roka zúčastnit nejakej formy vzdelávania v oblasti IKT. 69,44 \% opýtaných manažérov sa plánuje vzdelávat' v oblasti IKT.

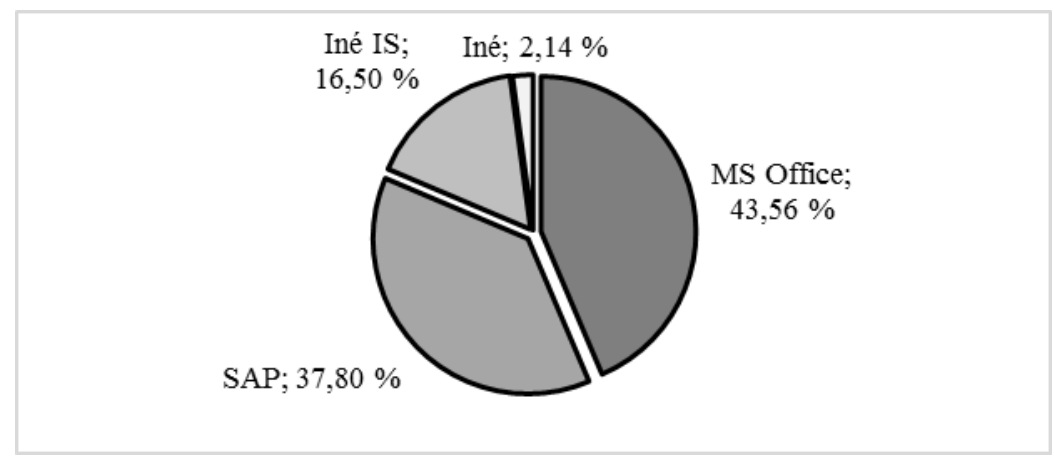

Graf č. 1: Oblasti budúceho vzdelávania manažérov v IKT

43,56 \% manažérov by sa v budúcnosti chcelo najčastejšie vzdelávat' v aplikáciách kancelárskeho balíka MS Office, kde primárnym ciel’om je prehíbenie poznatkov z ekonomických aplikácií v MS Excel. Školenie v práci so systémom SAP a jednotlivých modulov pre výkon pracovnej pozície plánuje 37,80 \% manažérov. $16,50 \%$ manažérov sa chce vzdelávat' v oblasti špecifických informačných systémov vzhl'adom na zameranie podniku a pracovnú pozíciu (napr. CRM, Helios, Kros, Pohoda, SQL, EDI, CAD, Karat a iné). Zvyšná čast' 2,14 \% respondentov sa chce zamerat' na operačné systémy (Windows, Linux), tvorbu webových stránok, autorské právo a legislatívu, virtualizáciu, správu sietí.

Pri zist'ovaní nutnosti absolvovat' školenie $\mathrm{v}$ oblasti IKT pred a po nástupe sme u manažérov zistovali aj ako na nich vplývajú jednotlivé podnety $\mathrm{k}$ vzdelávaniu. Respondenti pridel'ovali jednotlivým podnetom body zo škály 0 - neovplyvňujúci podnet až 10 - najvýznamnejší podnet $\mathrm{k}$ rozhodnutiu $\mathrm{k}$ vzdelávaniu, na základe čoho sme zostavili poradie preferencií. Agregované výsledky uvádzame v nasledujúcej tabul'ke č. 2. 


\begin{tabular}{|l|r|r|}
\hline Podnet & \multicolumn{1}{|c|}{$\sum$} & \% \\
\hline Záujem o osobný rast & 1394 & 20,70 \\
\hline Možnost' lepšieho uplatnenia & 1272 & 18,89 \\
\hline Budovanie kariéry & 1223 & 18,16 \\
\hline Požiadavka zamestnávatel'a & 1129 & 16,77 \\
\hline Záujem o nové trendy v IKT & 1094 & 16,25 \\
\hline Odporučenie známeho & 622 & 9,24 \\
\hline
\end{tabular}

Tab. č. 2: Podnety vedúce $k$ vzdelávaniu manažérov v IKT

Manažéri považujú za najvýznamnejší podnet, ktorý ich vedie ku vzdelávaniu, záujem o osobný rast, následne možnost' lepšieho uplatnenia v zamestnaní a na trhu práce, čo vedie $\mathrm{k}$ budovaniu ich kariéry. Za najmenej významný vplyv považujú odporúčania známeho na jednotlivé školenia. Respondenti mali možnost' uviest' aj vlastný podnet, ktorý ovplyvnil ich rozhodnutie. Až $63 \%$ manažérov uviedlo v otvorenej otázke úsporu nákladov vynaložených na IKT, ktoré zvyšujú produktivitu práce.

V rámci analýzy výsledkov prieskumu sme zistovali štatistickú významnost' na hladine významnosti $\alpha=0,05$ jednotlivých premenných (pohlavie, vek, pracovná pozícia, vzdelanie) na podnety vedúce $\mathrm{k}$ vzdelávaniu $\mathrm{v}$ oblasti IKT a zvyšovaniu úrovne informačnej gramotnosti. Pri testovaní sme využili Leveneho test, pomocou ktorého sme potvrdili normálne rozdelenie dát. V závislosti od počtu stupňov vol’nosti sme použili Independent Samples t-test. Pri testovaní ukazovatel'ov bol využitý Leveneho test pre potvrdenie normálneho rozdelenia dát. Nie všetky dáta jednotlivých ukazovatel'ov boli normálne rozdelené. Pri tých, ktoré spíňali túto podmienku, sme aplikovali Independent Samples t-test.

Manažéri $(\mathrm{n}=124)$ sa odlišujú od manažérok $(\mathrm{n}=56)$ v podnetoch: požiadavky zamestnávatel'a $\mathrm{p}<0,011$, záujmy o nové trendy $\mathrm{v}$ IKT $\mathrm{p}<0,017$, ktoré ich vedú $\mathrm{k}$ zvyšovaniu úrovne informačnej gramotnosti a vzdelávaní sa voblasti IKT. Predovšetkým manažéri vnímajú vyššie kladené požiadavky zamestnávatelom na ich zručnosti a znalosti v oblasti IKT, informačnej gramotnosti 64,92 \%, manažérky 35,08 \%. Záujem o nové trendy je výrazne vyšší u manažérov 72,76 \% ako u manažérok $27,24 \%$. Pohlavie respondentov je štatisticky významným činitel'om vo vztahu zvyšujúcich sa požiadaviek zamestnávatel'a na informačnú gramotnost' zamestnancov a záujem manažérov o nové trendy v oblasti IKT. Na ostatné podnety nemá pohlavie respondentov signifikantný vplyv. Dáta pri premennej: odporučenie známeho, nesplńăi podmienku normálneho rozdelenia dát. Śtatistickú významnost' sme testovali pomocou neparametrického testu Mann-Whitney. Na základe výsledkov testovania sa štatistická významnost' nepotvrdila.

Dáta pri testovaní signifikantného vplyvu veku na jednotlivé premenné splńali podmienku normálneho rozdelenia. Pri testovaní dát sme využili parametrický test One Way Anova s Bonferroniho korekciou. Respondenti boli segmentovaní do piatich vekových skupín: a) $18-25(\mathrm{n}=10)$, b) $26-35(\mathrm{n}=67)$, c) $36-45(\mathrm{n}=49)$, d) $46-55$ $(\mathrm{n}=47)$, e) $56-65(\mathrm{n}=7)$. 


\begin{tabular}{|c|c|c|c|c|c|c|}
\hline \multicolumn{2}{|l|}{ Podnet } & $\begin{array}{c}\text { Sum of } \\
\text { Squares }\end{array}$ & df & $\begin{array}{c}\text { Mean } \\
\text { Square }\end{array}$ & $\mathbf{F}$ & Sig. \\
\hline \multirow{3}{*}{$\begin{array}{l}\text { Záujem } \\
\text { o osobný rast }\end{array}$} & \begin{tabular}{|l|} 
Between \\
Groups
\end{tabular} & 9,994 & 4 & 2,499 & 0,489 & 0,744 \\
\hline & \begin{tabular}{|l|} 
Within \\
Groups \\
\end{tabular} & 894,250 & 175 & 5,110 & & \\
\hline & \begin{tabular}{|l|} 
Total \\
\end{tabular} & 904,244 & 179 & & & \\
\hline \multirow{3}{*}{$\begin{array}{l}\text { Možnost' } \\
\text { lepšieho } \\
\text { uplatnenia }\end{array}$} & $\begin{array}{l}\text { Between } \\
\text { Groups }\end{array}$ & 91,357 & 4 & 22,839 & 3,627 & $\mathbf{0 , 0 0 7}$ \\
\hline & \begin{tabular}{|l|} 
Within \\
Groups
\end{tabular} & 1101,843 & 175 & 6,296 & & \\
\hline & Total & 1193,200 & 179 & & & \\
\hline \multirow{3}{*}{$\begin{array}{l}\text { Budovanie } \\
\text { kariéry }\end{array}$} & \begin{tabular}{|l|} 
Between \\
Groups
\end{tabular} & 90,957 & 4 & 22,739 & 3,298 & 0,012 \\
\hline & $\begin{array}{l}\text { Within } \\
\text { Groups }\end{array}$ & 1206,437 & 175 & 6,894 & & \\
\hline & \begin{tabular}{|l|} 
Total \\
\end{tabular} & 1297,394 & 179 & & & \\
\hline \multirow{3}{*}{$\begin{array}{l}\text { Požiadavka } \\
\text { zamestnávatel'a }\end{array}$} & $\begin{array}{l}\text { Between } \\
\text { Groups }\end{array}$ & 32,891 & 4 & 8,223 & 1,020 & 0,398 \\
\hline & \begin{tabular}{|l|} 
Within \\
Groups
\end{tabular} & 1410,770 & 175 & 8,062 & & \\
\hline & Total & 1443,661 & 179 & & & \\
\hline \multirow{3}{*}{$\begin{array}{l}\text { Záujem o nové } \\
\text { trendy }\end{array}$} & \begin{tabular}{|l} 
Between \\
Groups
\end{tabular} & 52,392 & 4 & 13,098 & 1,625 & 0,170 \\
\hline & $\begin{array}{l}\text { Within } \\
\text { Groups }\end{array}$ & 1410,519 & 175 & 8,060 & & \\
\hline & \begin{tabular}{|l|} 
Total \\
\end{tabular} & 1462,911 & 179 & & & \\
\hline \multirow{3}{*}{$\begin{array}{l}\text { Odporučenie } \\
\text { známeho }\end{array}$} & $\begin{array}{l}\text { Between } \\
\text { Groups }\end{array}$ & 31,020 & 4 & 7,755 & 1,137 & 0,341 \\
\hline & $\begin{array}{l}\text { Within } \\
\text { Groups }\end{array}$ & 1193,624 & 175 & 6,821 & & \\
\hline & Total & 1224,644 & 179 & & & \\
\hline
\end{tabular}

Tab. č. 3: Testovanie odlišností podnetov v závislosti od vekovej skupiny

Signifikantné rozdiely medzi vekovými skupinami sa preukázali v prípade premenných možnost' lepšieho uplatnenia $\mathrm{p}<0,007$ a budovanie kariéry $\mathrm{p}<0,012$. Veková skupiny respondentov má štatisticky významný vplyv na možnost' uplatnenia sa na trhu práce a budovanie si kariéry. Možnost' lepšieho uplatnenia na trhu práce rozvíjaním znalostí a zručností $\mathrm{v}$ oblasti IKT a zvyšovaním úrovne informačnej gramotnosti vníma predovšetkým 2. veková skupina od 26 do 35 rokov $(39,78 \%$ ), následne 3. od 36 do 45 rokov (27,67 \%) a 4. veková skupina od 46 do 55 rokov $(22,17$ $\%$ ). 2. veková skupina zároveň najvýznamnejšie vníma možnost' budovania kariéry vo vzt’ahu k zvyšovaniu úrovne informačnej gramotnosti $38,18 \%$. Obdobne nasleduje 3 . $(28,45 \%)$ a 4 . veková skupina $(23,14 \%)$. 
Následne sme analyzovali štatistickú významnost' vplyvu pracovnej pozície na jednotlivé premenné. Pri testovaní normality rozdelenia dát sme využili Leveneho test. Všetky dáta boli normálne rozdelené. V nasledujúcej tabul'ke uvádzame výsledky testovania pomocou parametrického testu One - Way Anova s Bonferroniho korekciou. Respondenti sú rozdelení podl'a úrovní manažmentu: 1. - operatívny manažment $(\mathrm{n}=58), 2$. taktický manažment $(\mathrm{n}=77), 3$. vrcholový, top manažment $(\mathrm{n}=45)$.

\begin{tabular}{|c|c|c|c|c|c|c|}
\hline \multicolumn{2}{|l|}{ Podnet } & $\begin{array}{c}\text { Sum of } \\
\text { Squares }\end{array}$ & df & $\begin{array}{c}\text { Mean } \\
\text { Square }\end{array}$ & F & Sig. \\
\hline \multirow{3}{*}{$\begin{array}{l}\text { Záujem } \\
\text { o osobný rast }\end{array}$} & \begin{tabular}{|l|} 
Between \\
Groups
\end{tabular} & 0,886 & 2 & 0,443 & 0,087 & 0,917 \\
\hline & \begin{tabular}{|l|} 
Within \\
Groups \\
\end{tabular} & 903,358 & 177 & 5,104 & & \\
\hline & Total & 904,244 & 179 & & & \\
\hline \multirow{3}{*}{$\begin{array}{l}\text { Možnost' } \\
\text { lepšieho } \\
\text { uplatnenia }\end{array}$} & \begin{tabular}{|l} 
Between \\
Groups
\end{tabular} & 117,713 & 2 & 58,856 & 9,686 & 0,000 \\
\hline & \begin{tabular}{|l|} 
Within \\
Groups
\end{tabular} & 1075,487 & 177 & 6,076 & & \\
\hline & Total & 1193,200 & 179 & & & \\
\hline \multirow{3}{*}{$\begin{array}{l}\text { Budovanie } \\
\text { kariéry }\end{array}$} & $\begin{array}{l}\text { Between } \\
\text { Groups }\end{array}$ & 56,819 & 2 & 28,410 & 4,053 & $\mathbf{0 , 0 1 9}$ \\
\hline & $\begin{array}{l}\text { Within } \\
\text { Groups }\end{array}$ & 1240,575 & 177 & 7,009 & & \\
\hline & Total & 1297,394 & 179 & & & \\
\hline \multirow{3}{*}{$\begin{array}{l}\text { Požiadavka } \\
\text { zamestnávatel’a }\end{array}$} & $\begin{array}{l}\text { Between } \\
\text { Groups }\end{array}$ & 61,157 & 2 & 30,578 & 3,915 & 0,022 \\
\hline & \begin{tabular}{|l|} 
Within \\
Groups \\
\end{tabular} & 1382,504 & 177 & 7,811 & & \\
\hline & Total & 1443,661 & 179 & & & \\
\hline \multirow{3}{*}{$\begin{array}{l}\text { Záujem o nové } \\
\text { trendy }\end{array}$} & $\begin{array}{l}\text { Between } \\
\text { Groups }\end{array}$ & 66,587 & 2 & 33,293 & 4,220 & 0,016 \\
\hline & \begin{tabular}{|l|} 
Within \\
Groups \\
\end{tabular} & 1396,325 & 177 & 7,889 & & \\
\hline & Total & 1462,911 & 179 & & & \\
\hline \multirow{3}{*}{$\begin{array}{l}\text { Odporučenie } \\
\text { známeho }\end{array}$} & $\begin{array}{l}\text { Between } \\
\text { Groups }\end{array}$ & 32,541 & 2 & 16,270 & 2,416 & ,092 \\
\hline & \begin{tabular}{|l|} 
Within \\
Groups \\
\end{tabular} & 1192,104 & 177 & 6,735 & & \\
\hline & Total & 1224,644 & 179 & & & \\
\hline
\end{tabular}

Tab. č. 4: Testovanie odlišností podnetov v závislosti od pracovnej pozície 
Vplyv pracovnej pozície je štatisticky významný na možnost' lepšieho uplatnenia respondentov $\mathrm{p}<0,000$, budovanie kariéry $\mathrm{p}<0,019$, požiadavky zamestnávatel’a $\mathrm{p}<0,022$, záujem o nové trendy $\mathrm{p}<0,016$. Vnímanie respondentov ( $\mathrm{v}$ závislosti od pracovnej pozície - operatívni, taktickí, vrcholoví manažéri) zvyšovane úrovne informačnej gramotnosti, resp. rozširovanie znalostí a zručností vo vzt’ahu k možnostiam lepšieho uplatnenia, budovania kariéry, požiadavky zamestnávatel’a, záujem o nové trendy je najvýraznejšie u operatívnych manažérov, ktorí zväčša prešli z taktickej úrovne (budovali si kariéru) a majú d’alšiu možnost' kariérne rást'. Na týchto manažérov sú obvykle kladené aj vyššie požiadavky na ich úroveň informačnej gramotnosti a pre ulahčenie a zefektívnenie svojej práce sa častejšie zaujímajú aj o nové trendy v oblasti IKT.

Poslednou oblast'ou analýzy vplyvu je zhodnotenie štatistickej významnosti vplyvu vzdelania manažérov na jednotlivé premenné. Pri testovaní normality rozdelenia dát sme využili Leveneho test. Všetky dáta splňali podmienku normálneho rozdelenia dát. V nasledujúcej tabul'ke uvádzame výsledky testovania pomocou parametrického testu One - Way Anova s Bonferroniho korekciou. Manažérov sme segmentovali na základe dosiahnutého vzdelania: a) stredoškolské s maturitou $(\mathrm{n}=39)$, b) I. stupeň vysokoškolského vzdelania $(\mathrm{n}=9)$, c) II. stupeň vysokoškolského vzdelania $(\mathrm{n}=125)$, d) III. stupeň vysokoškolského vzdelania $(\mathrm{n}=7)$.

\begin{tabular}{|c|c|c|c|c|c|c|}
\hline \multicolumn{2}{|l|}{ Podnet } & $\begin{array}{c}\text { Sum of } \\
\text { Squares }\end{array}$ & df & $\begin{array}{c}\text { Mean } \\
\text { Square }\end{array}$ & $\mathbf{F}$ & Sig. \\
\hline \multirow{3}{*}{$\begin{array}{l}\text { Záujem } \\
\text { o osobný rast }\end{array}$} & Between Groups & 2,463 & 3 & 0,821 & 0,160 & 0,923 \\
\hline & Within Groups & 901,782 & 176 & 5,124 & & \\
\hline & Total & 904,244 & 179 & & & \\
\hline \multirow{3}{*}{$\begin{array}{l}\text { Možnost' } \\
\text { lepšieho } \\
\text { uplatnenia }\end{array}$} & Between Groups & 62,592 & 3 & 20,864 & 3,248 & 0,023 \\
\hline & Within Groups & 1130,608 & 176 & 6,424 & & \\
\hline & Total & 1193,200 & 179 & & & \\
\hline \multirow{3}{*}{$\begin{array}{l}\text { Budovanie } \\
\text { kariéry }\end{array}$} & Between Groups & 20,888 & 3 & 6,963 & 0,960 & 0,413 \\
\hline & Within Groups & 1276,506 & 176 & 7,253 & & \\
\hline & Total & 1297,394 & 179 & & & \\
\hline \multirow{3}{*}{$\begin{array}{l}\text { Požiadavka } \\
\text { zamestnávatel'a }\end{array}$} & Between Groups & 58,028 & 3 & 19,343 & 2,457 & 0,065 \\
\hline & Within Groups & 1385,633 & 176 & 7,873 & & \\
\hline & Total & 1443,661 & 179 & & & \\
\hline \multirow{3}{*}{$\begin{array}{l}\text { Záujem o nové } \\
\text { trendy }\end{array}$} & Between Groups & 51,126 & 3 & 17,042 & 2,125 & 0,099 \\
\hline & Within Groups & 1411,785 & 176 & 8,022 & & \\
\hline & Total & 1462,911 & 179 & & & \\
\hline
\end{tabular}




\begin{tabular}{|l|l|r|r|r|r|r|}
\hline \multirow{3}{*}{$\begin{array}{l}\text { Odporučenie } \\
\text { známeho }\end{array}$} & Between Groups & 8,633 & 3 & 2,878 & 0,416 & 0,741 \\
\cline { 2 - 7 } & Within Groups & 1216,011 & 176 & 6,909 & & \\
\cline { 2 - 7 } & Total & 1224,644 & 179 & & & \\
\hline
\end{tabular}

Tab. č. 5: Testovanie odlišností podnetov v závislosti od vzdelania

Vzdelanie manažéra má signifikantný vplyv na možnost' lepšieho uplatnenia sa na trhu práce $\mathrm{p}<0,023$. Respondenti $\mathrm{z}$ dosiahnutým II. stupňom vysokoškolského vzdelania vnímajú, že dosahujú lepšie uplatnenie na trhu práce $(70,68 \%)$. Z bežne dostupných štatistík možno dedukovat', že so zvyšujúcim sa vzdelaním rastie možnost' uplatnenia sa na trhu práce. U ostatných premenných sa vplyv úrovne vzdelania nepotvrdil.

\section{Diskusia}

Využitie IKT manažérmi v podniku je nevyhnutnou súčastou každodenného života. Manažéri majú pozitívny postoj k vzdelávaniu v oblasti IKT a sú si vedomí, že zvýšenie ich úrovne gramotnosti má pozitívny prínos nielen pre nich, ale i organizáciu. Manažéri najčastejšie vyhl'adávajú rôzne školenia a kurzy $\mathrm{v}$ oblasti prehíbenia poznatkov z ekonomických aplikácií $\mathrm{v}$ MS Excel a podnikových informačných systémov, napr. SAP. Väčšina manažérov má pozitívny postoj $\mathrm{k}$ vzdelávaniu $\mathrm{v}$ oblasti IKT. Ich postoj $\mathrm{k}$ vzdelávaniu v oblasti IKT sa formuje predovšetkým po nástupe do zamestnania, kedy pocitujú väčšiu potrebu vzdelávania sa. $\mathrm{K}$ vzdelávaniu sa $\mathrm{v}$ oblasti IKT ich vedie viacero podnetov. Za najvýznamnejší podnet považujú osobný rast 20,70 \%, možnost' lepšieho uplatnenia $18,89 \%$ a budovanie kariéry $18,16 \%$. Získané znalosti a zručnosti vzdelávaním v tejto oblasti sú významnými inhibítormi k osobnému rastu a lepšiemu uplatneniu sa. Opodstatnenost' vzdelávania a zvyšovanie úrovne informačnej gramotnosti vo vzt'ahu uplatnenia sa na trhu práce zdôrazňuje Kokles a kol. (2014). Na vnímanie jednotlivých podnetov, ktoré manažérov vedú $\mathrm{k}$ vzdelávaniu sa $\mathrm{v}$ oblasti IKT má signifikantný vplyv viacero faktorov. Jedným z nich je pohlavie manažérov. Manažéri a manažérky sa predovšetkým štatisticky významne odlišujú vo vnímaní podnetov: požiadavky kladené na nich zamestnávatel’om: a) muži $(64,92 \%)$, b) ženy $(35,08 \%)$ a záujem o nové trendy v oblasti IKT: a) muži $(72,76 \%)$, b) ženy $(27,24 \%)$. Štatisticky je verifikované, že manažéri vnímajú vyššie požiadavky kladené na ich prácu s IKT a majú väčší záujem o nové trendy v oblasti IKT.

Dalším významným faktorom je vek manažérov. V závislosti od vekovej skupiny sa signifikantne odlišujú v možnostiach lepšieho uplatnenia sa na trhu práce: a) $18-25$ $(6,68 \%)$, b) $26-35(39,78 \%)$, c) $36-45(27,67 \%)$, d) $46-55(22,17 \%)$, e) $56-65$ $(3,69 \%)$. Pri premennej: budovania kariéry, dosahujú manažéri v závislosti od vekovej skupiny nasledované hodnoty: a) 18 - $25(7,20 \%)$, b) $26-35(38,18 \%)$, c) $36-45$ $(28,45 \%)$, d) $46-55(23,14 \%)$, e) $56-65$ (3,03 \%). Manažéri sa vzdelávajú predovšetkým po nástupe do zamestnania, kedy práve vplyv úrovne znalostí a zručností v oblasti IKT je významný na ich uplatnenie sa v zamestnaní a budovanie kariéry. Tento podnet najviac ovplyvňuje vekovú skupinu b), c) a d).

Pracovná pozícia signifikantne ovplyvňuje vnímanie možnosti lepšieho uplatnenia sa v zamestnaní, resp. na trhu práce: 1 . operatívny manažment $(34,20 \%)$, 2. taktický 
manažment (45,75 \%), 3. vrcholový manažment (20,05 \%). Pracovná pozícia štatisticky významne vplýva aj na premennú - budovania kariéry: 1 . operatívny manažment $(33,61 \%)$, 2. taktický manažment $(44,97 \%)$, 3 . vrcholový manažment $(21,42 \%)$ a premennú - záujem o nové trendy v oblasti IKT: 1 . operatívny manažment $(29,16 \%)$, 2. taktický manažment $(47,71 \%), 3$. vrcholový manažment $(23,13 \%)$. Najvýraznejší vplyv možno identifikovat' u manažérov strednej úrovne riadenia, ktorí majú väčší záujem budovat' si kariéru, upevňovat' svoje postavenie $\mathrm{v}$ zamestnaní a majú najväčší záujem o nové trendy v IKT, pretože IKT sa stali súčastou ich každodennej práce, uvedomujú si ich význam a potrebu nadobudnutia, resp. zdokonalenia znalostí, zručností $\mathrm{v}$ tejto problematike.

Dosiahnutý stupeň vzdelania má štatisticky významný vplyv predovšetkým na možnost' uplatnenia manažérov v zamestnaní, resp. na trhu práce: a) stredoškolské s maturitou $(21,86 \%)$, b) I. stupeň vysokoškolského vzdelania $(5,19 \%)$, c) II. stupeň vysokoškolského vzdelania (70,68 \%), d) III. stupeň vysokoškolského vzdelania $(2,28 \%)$. Predovšetkým manažéri s dosiahnutým II. stupňom vysokoškolského vzdelania považujú za najvýznamnejší podnet vedúci $\mathrm{k}$ vzdelávaniu v oblasti IKT možnost' ich lepšieho uplatnenia v zamestnaní, resp. posilnení pracovnej pozície. Neustálym d’alším vzdelávaním sa im otvára možnost' získania nových znalostí a zručností v oblasti IKT, ktoré dokážu ich prácu zefektívnit', poskytnút' relevantné informácie pre rozhodovanie a riadenie organizácie.

Figel' (2006) zdôrazňuje, že vzdelanie je významným kultúrnym činitel’om, pretože prostredníctvom lepšieho poznania možno presadzovat' etické a právne hodnoty, budovat' porozumenie, rešpekt, úctu, ktoré sú vel'mi dôležité pre medziludské, ale aj pre medzinárodné vzt’ahy. Pomáha pri zachovaní a rozvoji kultúrneho dedičstva, ktoré treba najprv poznat', osvojit' si ho, d’alej budovat' a odovzdávat' d’alším generáciám. Frk (2002) poukazuje na fakt, že vzdelávanie manažérov sa podriad’uje meniacej makroekonomickej situácii a mal by byt' dosiahnutý taký súhrn vedomostí, zručností, schopností a záujmov, ktoré prostredníctvom organizovaného procesu vzdelávania, ale aj cestou sebavýchovy, sebavzdelávania a tiež prostredníctvom neformálnych informačných zdrojov zabezpečí primeranú bázu pre kontinuálnu aktualizáciu. Stotožňujeme sa s názorom Fulkovej a Bošanského (2009), že dnešná doba potrebuje informovaného, tvorivého, samostatného, komunikatívneho, adaptabilného a vysoko odborne vzdelaného manažéra. Ním sa však môže stat' iba ten, kto sa chce neustále zdokonal'ovat' prostredníctvom celoživotného vzdelávania, vrátane sebavýchovy a sebavzdelávania. Tento predpoklad platí obzvlášt' pre riadiacich pracovníkov - manažérov, či už operatívnych, taktických alebo vrcholových manažérov.

Z pohl'adu celoživotného vzdelávania je dôležité vytvárat' a zabezpečovat' podmienky pre vzdelávanie $\mathrm{v}$ každom veku, zameraní uchádzača. Celoživotné vzdelávanie je významným nástrojom rozvoja osobnosti. V súčasnej dobe aj po skončení graduálneho vzdelávania je žiaduce pokračovat' v d’alšom vzdelávaní. Z výsledkov výskumu možno dedukovat', že najvýznamnejšími podnetmi motivujúcimi manažérov k vzdelávaniu je záujem o osobný rast, budovanie kariéry, posilnenie na trhu práce, možnost' lepšieho uplatnenia na trhu práce. Preto je potrebné, aby celoživotné vzdelávanie odzrkadlovalo požiadavky súčasnej doby, aby frekventantom vzdelávania poskytlo dostatok priestoru pre získanie, resp. rozvoj znalostí a zručností. Vzdelaný l'udský kapitál v podniku dokáže prispiet’ nielen k zvýšeniu produktivity práce, ale aj 
posilneniu konkurenčnej výhody. Preto ako tvrdia aj Mihalčová a Pružinský (2007) východiskom HR stratégie každého podniku by malo byt' presvedčenie, že vzdelávanie zamestnancov nie je len nákladom, ktorý treba minimalizovat', ale investícia do l'udského kapitálu, ktorý v budúcnosti bude prínosom. Manažéri majú záujem sa vzdelávat' $\mathrm{v}$ oblasti IKT, lebo podnety vedúce $\mathrm{k}$ ich vzdelávaniu sú významným motivátorom. Na celoživotnom vzdelávaní sa musia aktívne podiel'at' nielen samotní zamestnanci, ale aj podniky, organizácie formou aktívnej podpory svojich zamestnancov.

\section{Záver}

Dôležitým prostriedkom formovania schopností manažérov je sústavné vzdelávanie. Vedenie podnikov si uvedomuje, že sústavné vzdelávanie manažérov v každej oblasti spoločenského života je nevyhnutné. Manažéri musia disponovat takými znalostami, zručnostami a vedomost’ami, aby ich dokázali uplatnit' nielen pri riadení organizácií, ale predovšetkým pri strategickom rozhodovaní o dôležitých veciach, aby dokázali rozpoznávat' nové hrozby, príležitosti, riziká v konkurenčnom prostredí. Nielen podniky, ale aj manažéri si uvedomujú, že vedomosti získané formálnym vzdelávaním nepostačujú, že je žiaduce si ich dopíňat', prehlbovat' a rozširovat' $\mathrm{v}$ súlade $\mathrm{s}$ narastajúcimi požiadavkami organizácií $\mathrm{v}$ turbulentne sa rozvíjajúcej spoločnosti. Do popredia sa čoraz viac dostáva potreba d’alšieho vzdelávania, ako súčasti celoživotného vzdelávania, a to nielen $\mathrm{v}$ Slovenskej republike, ale $\mathrm{i}$ vo všetkých krajinách Európskej únie, ba i v celosvetovom meradle. Manažéri vnímajú značnú potrebu vzdelávania sa $\mathrm{v}$ oblasti IKT po nástupe do zamestnania. Väčšia čast' podnikov aktívne podporuje zamestnancov vo vzdelávaní, ktorí uprednostňujú formálne vzdelávanie. Predovšetkým ide o vzdelávanie sa voblasti kancelárskeho balíka MS Office a špecifických informačných systémov $\mathrm{v}$ oblasti ich pôsobenia. Medzi najvýznamnejšie podnety vedúce $\mathrm{k}$ vzdelávaniu $\mathrm{v}$ oblasti IKT je záujem manažérov o osobný rast, možnost' lepšieho uplatnenia v zamestnaní, resp. na trhu práce, posilnení pracovnej pozície a manažéri sa vzdelávajú aj za účelom budovania kariéry. Významným faktorom sú aj neustále sa zvyšujúce požiadavky zamestnávatel’ov kladené na znalosti a zručnosti zamestnancov v oblasti IKT. Z parciálnych výsledkov uskutočnenej analýzy prieskumu v Slovenskej republike na vzorke 180 respondentov, manažérov možno identifikovat' signifikantné faktory ovplyvňujúce vnímanie jednotlivých podnetov vedúcich $\mathrm{k}$ vzdelávaniu $\mathrm{v}$ oblasti IKT a zvyšovaniu úrovne informačnej gramotnosti. V záveroch možno dedukovat', že vzdelávanie manažérov v IKT je žiaduce a manažéri, ktorí nepochopili význam IKT a neustáleho celoživotného vzdelávania môžu zostat' na okraji znalostnej, digitálnej spoločnosti.

\section{Pod'akovanie}

Príspevok bol spracovaný v rámci projektu Ekonomickej univerzity v Bratislave pre mladých učitel’ov, vedeckých pracovníkov a doktorandov v dennej forme štúdia č. I-16$107-00$. 


\section{Literatúra}

Balaisiene, J. (2010). Motivating adult learners'participation and persistence in lifelong learning processes. Cluj-Napoca: Consorţiul Internaţional Lectura şi Scrierea pentru Dezvoltarea Gândirii Critice

Eurostat. (2012). Epp.eurostat.ec.europa.eu. Dostupné na internete: Lifelong learning statistics: http://epp.eurostat.ec.europa.eu/statistics_explained/index.php/ Lifelong learning_statistics

Farson, R. (1997). Management of the Absurd: Paradoxes in Leadership. New York: Touchstone.

Figel', J. (2006). Vzdelanie - klúč k budúcnosti Európy. Nadácia Konrada Adenauera:

Bratislava. Dostupné na internete: 〈http://www.kas.de/wf/doc/kas_8548-1522-1〉

Frk, V. (2002). Vzdelávanie manažérov a príčiny ich negatívnych postojov k vzdelávaniu. Vzdelávanie dospelých. Bratislava: AIVD, 2002, roč. 7, č. 1, s. 18-25.

Fulková, E. \& Bošanský, B. (2009). Celoživotné vzdelávanie manažérov - teória a prax. Quo vadis cvičná firma - nové trendy v cvičnej firme: zborník medzinárodnej vedeckej konferencie. Bratislava: Ekonóm.

Keogh, H. (2007). Vzdelávanie dospelých bez odborného zamerania v Európe. Zhrnutie dôležitých národných informácií z databázy Eurybase (s. 11). Brussels: Eurydice.

Kokles, M., Romanová , A., \& Hamranová, A. (2015). Information Systems in the posttransition period in enterprises in Slovakia. Journal of global information technology management., 110-126.

Kokles, M., Romanová, A., \& Hamranová, A. (2014). The Influence of education and of other factors on the level of digital literacy. ICT in educational design : processes, materials, resources, , 36-60.

Kubiatko, M. (2013). The Perception and Using of ICT in the different Age. Journal of Technology and Information Education, 35-41.

Kusá, Z. (2005). Kvalitatívny výskum v spoločenskej vede a sociálnej práci. Bratislava: Univerzita Komenského.

Mihalčová, B., \& Pružinský, M., (2007). Celoživotní vzdělávání se stává standardem. Moderní rízení. 1-2.

Prokopenko, J., \& Kubr, M. (1996). Vzdělávaní a rozvoj manažeru. Praha: Grada.

Šubertová, E. (2009). Podnikanie v malých a stredných podnikoch pre manažérov. Bratislava: Ekonóm.

Švec, Š. (2002). Základné pojmy v pedagogike a andragogike. Bratislava: Iris. 